\title{
EVALUASI KINERJA PT. PINDAD (PERSERO) DENGAN BALANCED SCORECARD
}

\author{
(Studi Kasus Pada PT. Pindad (Persero))
}

\author{
Diah Andari* \\ Universitas Widyatama, Jl. Cikutra no 204 A, Bandung - Jawa Barat, \\ Indonesia \\ *(diah.andari86@gmail.com)
}

\begin{abstract}
ABSTRAK
Penelitian ini bertujuan untuk mengevaluasi kinerja PT. Pindad (Persero) menggunakan Balanced Scorecard, yaitu terkait kinerja perusahaan dalam perspektif keuangan, perspektif pelanggan, perspektif proses bisnis internal, dan pembelajaran dan pertumbuhan. Untuk Perspektif Keuangan, kinerja organisasi sudah baik, tetapi ada beberapa indikator yang realisasinya belum sesuai dengan target yang ditetapkan oleh organisasi, seperti net profit margin, debt equity ratio, dan cash ratio. Evaluasi pada Perspektif Pelanggan ditinjau dari perspektif pelanggan menunjukkan bahwa kinerja organisasi telah baik yang dapat dilihat dari pencapaian target yang telah ditetapkan oleh organisasi. Untuk evaluasi Perspektif Proses Bisnis Internal, kinerja organisasi sudah baik sebagaimana dilihat dari tercapainya target-target yang sudah ditetapkan oleh organisasi. Tindak lanjut terhadap fraud dan jumlah kasus pending selanjutnya perlu dilakukan dan disiasati lebih awal sebelum penyimpangan tersebut mengakibatkan kerugian dikemudian hari karena akan secara signifikan mempengaruhi kelangsungan bisnis perusahaan. Evaluasi Pembelajaran \& Pertumbuhan Perspektif juga menunjukkan kinerja pertumbuhan yang telah baik itu dapat dilihat dari pencapaian target yang telah ditetapkan target oleh organisasi.
\end{abstract}

Kata kunci: Balanced Scorecard, Perspektif Keuangan, Perspektif Pelanggan, Perspektif Proses Bisnis Belajar Internal \& Perspektif Pertumbuhan

\begin{abstract}
This study aimed to evaluate the performance of PT. Pindad (Persero) using the Balanced Scorecard, which is related to the performance of companies in the financial perspective, customer perspective, internal business processes, and learning and growth. For the Financial Perspective, the organization's performance has been good, but there are some indicators that realization is not in accordance with the targets set by the organization, such as the net profit margin, debt equity ratio and cash ratio. Evaluation on Customer Perspective viewed from the perspective of customers shows that organizations have good performance that can be seen from achieving the targets set by the organization. For the evaluation of Internal Business Process Perspective, the organization's performance has been good, as seen from the achievement of the targets set by the organization. Follow-up of the fraud and the number of cases pending further needs to be done and to be handled early before the irregularity resulting in losses in the future because it will significantly affect the company's business continuity. Evaluation of Learning \& Growth Perspective also
\end{abstract}


showed growth performance has been good it can be seen from the achievement of the targets set by the target organization.

Keywords: Balanced Scorecard, Financial Perspective, Customer Perspective, Internal Business Process Perspective, Learning \& Growth Perspective.

\section{PENDAHULUAN}

Pada saat ini persaingan bisnis antar perusahaan-perusahaan didunia semakin ketat sehingga menuntut para pengambil kebijakan untuk selalu bertindak dan berperilaku efisien dan seoptimal mungkin menciptakan utilisasi dalam proses produksinya. Untuk itu perusahaan-perusahaan harus melakukan berbagai macam strategi dalam menghadapi persaingan tersebut agar perusahaan dapat terus bertahan, berkembang dan maju sehingga tidak kalah bersaing dan hilang keberadaannya karena kalah dalam persaingan.

Setiap perusahaan dituntut untuk dapat memperbaiki kemampuannya dalam berbagai bidang agar dapat terus bersaing mencapai kualitas sumber daya manusia yang kompeten di era globalisasi seperti sekarang ini dan dapat ikut berperan serta dalam membangun pondasi ekonomi nasional. Salah satu unsur yang menopang struktur ekonomi nasional pada saat ini yaitu bidang industri.
Perusahaan industri pada saat ini saling bersaing satu sama lain untuk menghasilkan barang dan jasa dengan menawarkan kelebihannya masing-masing.

Hansen dan Mowen (2004) mengemukakan bahwa dengan perkembangan seperti ini, setiap perusahaan harus berusaha menghasilkan produk yang memiliki nilai lebih dari pesaingnya. Hal ini mengakibatkan persaingan yang semakin ketat antara produsen penghasil barang dan jasa. Kunci persaingan dalam pasar global adalah service yang berarti, produk yang berkualitas, harga yang relatif murah, dan penyerahan tepat waktu. Dengan demikian perusahaan akan meraih kepuasan pelanggan secara terus menerus hingga tercipta pelanggan yang loyal.

Pengukuran kinerja suatu organisasi atau perusahaan pada umumnya menggunakan ukuran kinerja financial yang memiliki keterbatasan. Keterbatasan ukuran kinerja keuangan yang tidak konsisten dengan kondisi keuangan 
saat ini dimana laporan keuangan hanya memuat aset berwujud. Sedangkan aset tidak berwujud yang dilaporkan dalam laporan keuangan hanya terbatas pada goodwill dan paten. Padahal masih banyak jenis aset tidak berwujud lain yang tidak dicantumkan dalam laporan keuangan seperti nama baik, hubungan baik dengan pelanggan, supplier dan distributor. Kelemahan kedua adalah ukuran kinerja keuangan merupakan data historis, jadi baru dicatatkan kalau sudah terjadi transaksi dimana kejadian tersebut tentu akan berulang di masa yang akan datang. Sehingga ukuran kinerja keuangan tidak dapat dijadikan sebagai pedoman bagi perusahaan untuk melakukan aktifitas di masa depan.

Selanjutnya ukuran kinerja keuangan merupakan ukuran keuangan yang merupakan ukuran secara fungsional, tidak secara keseluruhan. Hal ini disebabkan karena pada umumnya ukuran kinerja keuangan disiapkan oleh masing-masing area fungsional, misalnya pemasaran dan keuangan. Dengan demikian kinerja keuangan tidak dapat dijadikan sebagai alat untuk mencerminkan perusahaan secara keseluruhan. Keterbatasan ukuran kinerja yang lain adalah fokus pada keuntungan jangka pendek, sehingga keuntungan jangka panjang akan terabaikan dan menjadi tidak relevan untuk dijadikan sebagai dasar keputusan bagi beberapa level dalam organisasi.

Adanya keterbatasan di dalam pengukuran kinerja keuangan akan membuat banyak perusahaan mulai menggunakan Balanced Scorecard. Konsep Balanced Scorecard yang pertama kali dipublikasikan oleh Robert S. Kaplan dan David P. Norton dalam artikel yang berjudul "Balanced Scorecard-Measures that Drive Performance" pada tahun 1992, yang memungkinkan manajemen perusahan memandang perusahaan dari empat perspektif, yaitu perspektif keuangan (financial perspective), perspektif pelanggan (customer perspective), perspektif internal (internal perspective) dan perspektif pertumbuhan dan pembelajaran (learning and growth perspective). Selain itu, Balanced Scorecard bukan hanya sekedar alat pengukur kinerja tetapi juga merupakan suatu sarana untuk mengelola proses, yang mana dalam pengembangan Balanced Scorecard, perusahaan dapat mengklarifikasi serta menerjemahkan visi serta strategi secara total kepada seluruh tingkatan dalam suatu organisasi.

Fenomena yang terjadi di PT. PINDAD (Persero) ini adalah terdapat 
beberapa kekurangan di dalam pelaksanaan sistem kinerja berbasis Balance Scorecard di PT PINDAD (Persero), seperti halnya ada beberapa indikator kinerja didalam perspektif yang sudah ada tidak dilaksanakan sesuai dengan standar yang telah ditetapkan. Pada satu sisi, terlihat bahwa KPI pada perspektif customer yang berisi mengenai pertumbuhan pendapatan penjualan dan on time delivery belum sepenuhnya mencerminkan kepuasan pelanggan karena kepuasan pelanggan itu tidak hanya dilihat dari 2 aspek tersebut tetapi juga mencakup beberapa hal antara lain kualitas produk dan customer complaint.

Dengan mencermati fenomena diatas maka peneliti memilih perusahaan ini sebagai tempat penelitian dengan pertimbangan bahwa perusahaan ini telah menerapkan sistem pengukuran Balanced Scorecard. Perusahaan ini telah menggunakan scorecard sebagai sebuah sistem manajemen strategis jangka panjang. Keberhasilan penerapan Balanced Scorecard sangat ditentukan oleh proses penyusunan atau pengembangan Balanced Scorecard. Perusahaan menggunakan fokus pengukuran scorecard sebagai alat untuk penilaian kinerja perusahaan. Evaluasi sangat penting dilakukan, dengan adanya pengkajian terhadap hasil yang telah dicapai dan yang belum dicapai akan digunakan sebagai data dalam pengambilan keputusan jangka panjang. PT. PINDAD (Persero) merupakan satusatunya perusahaan BUMN di Indonesia yang bergerak di bidang manufaktur peralatan pertahanan dan keamanan. Dengan adanya persaingan kompetitif yang dihadapi saat ini, perusahaan harus merumuskan perencanaan strategi untuk dapat mempertahankan kelangsungan hidup perusahaan. PT. PINDAD (Persero) menggunakan Balanced Scorecard sebagai pengukuran kinerjanya. Manajer perusahaan dapat mengukur apa yang telah mereka targetkan dengan realisasi yang dapat dicapai. Berdasarkan uraian diatas, penulis tertarik untuk melakukan penelitian pada sektor industri pertahanan dengan memilih judul "EVALUASI KINERJA PT. PINDAD (Persero) DENGAN BALANCED SCORECARD

\section{TELAAH LITERATUR DAN PERUMUSAN HIPOTESIS}

Menurut Mulyadi (2007), penilaian kinerja adalah penentuan secara periodik efektifitas operasional suatu organisasi, bagian organisasi, dan personilnya berdasarkan sasaran strategi, standar, kriteria yang telah ditetapkan sebelumnya. Menurut 
Mulyadi (2001), pengukuran kinerja adalah penilaian secara periodik efektivitas suatu perusahaan dan karyawannya berdasarkan sasaran standard dan kriteria yang telah ditetapkan sebelumnya.

Menurut Mulyadi (2001), maksud atau tujuan umum pengukuran kinerja adalah:

a. Untuk menentukan kontribusi suatu bagian dari perusahaan terhadap organisasi secara keseluruhan.

b. Dapat dijadikan dasar dan penilaian mutu atau kualitas kinerja manajer.

c. Untuk memotivasi manajer dalam melaksanakan segala tugasnya sesuai dengan tujuan pokok organisasi secara keseluruhan.

Dalam persaingan bisnis global ini, perubahan paradigma yang ada harus dilandasi dengan suatu pemikiran baru bahwa competiveness dan efektivitas organisasi dapat dicapai dengan memperluas faktor faktor yang dianggap dapat mempengaruhi peningkatan produktivitas dan melakukan koordinasi dalam menghasilkan keuntungan kompetitif. Kemampuan perusahaan dalam menciptakan keunggulan kompetitif ini merupakan tanggung jawab yang kompleks yang harus dipikul oleh setiap perusahaan untuk dapat bertahan dalam jangka panjang.

\section{Balanced Scorecard}

Balanced Scorecard pertama kali dikembangkan pada awal tahun 1990an oleh Robert S.Kaplan dan David P. Norton, adalah Balanced Scorecard (BSC). Pemunculan Balanced Scorecard dilatarbelakangi oleh kondisi persaingan pasar yang semakin kompleks. Dengan adanya globalisasi, yang membuka jalur perdagangan bagi perusahaanperusahaan asing untuk berkompetisi di dalam negeri, informasi keuangan (sistem tradisional) menjadi tidak cukup untuk memampukan perusahaan menghadapi persaingan saat ini.

BalancedScorecard dimanfaatkan untuk menyeimbangkan usaha dan perhatian eksekutif kepada kinerja keuangan dan non-keuangan, serta kinerja jangka pendek dan kinerja jangka panjang. Dengan memperluas ukuran kinerja eksekutif ke kinerja nonkeuangan, ukuran kinerja eksekutif menjadi komprehensif. Balanced Scorecard memperluas ukuran kinerja eksekutif ke dalam empat perspektif: financial, customer, internal business process, serta learn and growth.

Konsep Balanced Scorecard telah lama dikembangkan oleh Robert 
S. Kaplan dan David P. Norton. Konsep Balanced Scorecard ini dikembangkan untuk melengkapi pengukuran kinerja keuangan (atau dikenal dengan pengukuran kinerja tradisional) dan sebagai alat yang cukup penting bagi organisasi. Kaplan dan Norton menggunakan empat standar perspektif Balanced Scorecard yaitu financial, customer, internal business process, dan learning and growth.

\section{Perspektif financial}

BalancedScorecard dibangun dari studi pengukuran kinerja di sektor bisnis, sehingga perspektif financial disini adalah terkait dengan financial suistainability. Perspektif ini digunakan oleh shareholder dalam rangka melakukan pengelolaan kinerja organisasi.

2. Perspektif customer

Perspektif customer adalah perspektif yang berorientasi pada pelanggan karena merekalah pemakai produk/jasa yang dihasilkan organisasi. Dengan kata lain, organisasi harus memperhatikan apa yang diinginkan oleh pelanggan.

3. Perspektif internal business process

Perspektif internal business process adalah serangkaian aktivitas yang ada dalam organisasi untuk menciptakan produk/jasa dalam rangka memenuhi harapan pelanggan. Perpektif ini menjelaskan proses bisnis yang dikelola untuk memberikan layanan dan nilainilai kepada stakeholder dan customer.

4. Perspektif learning and growth

Perspektif learning and growth adalah perspektif yang menggambarkan kemampuan organisasi untuk melakukan perbaikan dan perubahan dengan memanfaatkan sumber daya internal organisasi. Kesinambungan suatu organisasi dalam jangka panjang sangat bergantung pada perspektif ini.

Menurut Mulyadi terdapat beberapa keunggulan Balanced Scorecard dibandingkan dengan alat pengelolaan kinerja lainnya yaitu:

1. Meningkatkan secara signifikan kualitas perencanaan

2. Meningkatkan kualitas pengelolaan kinerja personel Balanced Scorecard mengembangkan seperangkat tujuan unit bisnis yang meliputi ukuran keuangan. Para eksekutif perusahaan sekarang dapat mengukur seberapa besar unit bisnis mereka dapat menciptakan nilai bagi para 
pelanggan perusahaan saat ini dan yang akan datang, dan seberapa banyak perusahaan harus meningkatkan kapabilitas internal dan investasi di dalam sumber daya manusia, sistem dan prosedur yang dibutuhkan untuk meningkatkan kinerja yang akan datang. Balanced Scorecard mencakup berbagai aktivitas penciptaan nilai yang dihasilkan oleh para partisipan perusahaan yang memiliki kemampuan dan motivasi tinggi. Sementara tetap memperhatikan kinerja jangka pendek, yaitu melalui perspektif keuangan. Balanced Scorecard dengan jelas mengungkapkan berbagai faktor yang menjadi pendorong tercapainya kinerja keuangan dan kompetitif jangka panjang yang superior.

Ada hal-hal yang harus diperhatikan dalam proses penyusunan Balanced Scorecard yaitu, untuk menggunakan sistem Balanced Scorecard, diperlukan komitmen dari seluruh anggota organisasi, waktu yang cukup dari tahap pengenalan hingga tahap penerapan Balanced Scorecard, serta tenaga ahli dan biaya.

Keterbatasan dalam Konsep Balanced Scorecard Menurut Kaplan dan Norton (1996), diungkapkan adanya "missing measures", yaitu suatu ukuran yang digunakan oleh perusahaan dalam Balanced Scorecard-nya, namun belum pernah melakukan pengukuran tersebut sebelumnya sehingga tidak tersedianya data untuk penilaian kinerja masa kini. Missing measures ini menandakan adanya proses yang terlewat untuk di kontrol perusahaan sehingga perusahaan perlu mengembangkan cara untuk mengontrol proses tersebut. Hubungan antar perspektif-perspektif Balanced Scorecard pun tidak mutlak hubungan sebab akibat, dimana output keuangan akan dicapai melalui pencapaian tujuan-tujuan pada perspektif lainnya. Kaplan dan Norton mengungkapkan hubungan sebab akibat, maka pelanggan yang loyal akan mengakibatkan peningkatan pendapatan. Namun hipotesa tersebut juga dapat berdampak negatif, karena pelanggan yang tidak profitable (kembali ke ukuran financial). Sehingga hubungan antar perspektif tersebut bukanlah suatu hubungan sebab akibat melainkan suatu hubungan yang interdependent. Dimana pencapaian tujuan-tujuan pada setiap perspektif membutuhkan kontribusi dari perspektif lainnya.

Keterbatasan lainnya adalah tidak dijelaskan lebih jauh bagaimana perusahaan dapat melakukan perubahan-perubahan dalam 
perspektif Balanced Scorecard. Seperti yang telah diungkapkan, Balanced Scorecard memberi kebebasan kepada penggunanya jika ingin mengganti salah satu perspektif dengan perspektif lain atau ingin menambah. Namun, tidak ada penjelasan ataupun dalam melakukan hal tersebut.

Konsep Balanced Scorecard juga terbatas pada faktor internal perusahaan dan tidak memperhitungkan faktor eksternal seperti persaingan pasar (seperti kinerja kompetitor, dsb) atau perkembangan teknologi yang juga memiliki dampak terhadap perusahaan. Balanced Scorecard juga merupakan top-down strategy. Hal ini dikarenakan umumnya visi, misi, serta strategi perusahaan ditetapkan oleh para pihak eksekutif dan kemudian dikomunikasikan ke seluruh bagian perusahaan. Proses yang demikian yang demikian merupakan proses penentuan yang efisien. Namun, keterbatasan dari proses tersebut adalah tidak berpartisipasinya karyawan, yang pada bagian tersebut dapat menghambat motivasi instrinsik karyawan untuk berperan aktif dan kreatif dalam mendorong kinerja perusahaan. Beberapa masalah yang mungkin perlu dicermati oleh perusahaan ketika akan mengimplementasikan konsep Balanced Scorecard dalam sistem pengukuran kinerjanya, karena akan dapat membatasi kegunaan dari konsep itu sendiri.

Permasalahan yang dimaksud adalah:

1. Adanya korelasi yang buruk antara pengukuran non keuangan dengan hasil yang diperoleh. Tidak adanya jaminan bahwa tingkat profitabilitas masa yang akan datang tercapai pada saat pencapaian target pada aspek non keuangan;

2. Tidak adanya mekanisme untuk proses perbaikan. Tanpa suatu metode untuk mengadakan proses berbaikan, menjadikan kondisi perusahaan tidak konsisten pada sasaran dan tujuan yang telah ditetapkan;

3. Alat ukur yang tidak up date. Banyak perusahaan yang tidak mempunyai mekanisme formal untuk memperbaharui alat ukurnya untuk disesuaikan dengan alat ukur yang didasarkan pada strategi yang telah lalu.

4. Alat ukur yang over load atau berlebihan, pekerjaan rumah bagi manajer akan memiliki keterbatasan dalam 
pengukuran, jika terlalu sedikit maka manajer akan mengabaikan alat pengukur kritis yang dapat mencapai kesuksesan. Sebaliknya, jika berlebihan manajer mungkin akan beresiko untuk kehilangan fokus pekerjaannya dan berusaha mengerjakan banyak tugas pada saat bersamaan.

Walau demikian, keterbatasanketerbatasan tersebut tidak mengurangi manfaat yang dapat diperoleh organisasi melalui penerapan Balanced Scorecard, melainkan menjadi hal-hal yang perlu diketahui agar dapat mengoptimalisasi Balanced Scorecard dengan berbagai keterbatasan tersebut.

\section{Cascading Process}

Cascading process ini dimanfaatkan untuk menetapkan peran dari setiap pusat pertanggungjawaban dalam mewujudkan sasaran strategik yang terdapat dalam company scorecard. Proses ini juga dapat digunakan untuk membangun komitmen seluruh personnel dengan cara mengikutsertakan semua komponen organisasi dalam mencapai sasaran strategik organisasi. Cascading merupakan alat untuk melakukan pengkomunikasian sasaran dan inisiatif strategik dari jenjang organisasi yang paling tinggi hingga tingkat yang paling bawah yaitu karyawan.

Mulyadi (2009) menyebutkan bahwa cascading adalah proses penyusunan scorecard di setiap jenjang organisasi oleh manajer jenjang organisasi yang bersangkutan, dengan menggunakan scorecard jenjang organisasi yang lebih tinggi sebagai basis. Melalui cascading process, setiap pusat pertanggungjawaban, tim dan personnel dapat menyusun scorecard yang mencerminkan: (1) kontribusi signifikan pusat pertanggungjawaban terhadap pencapaian sasaran strategik organisasi secara keseluruhan atau pusat pertanggungjawaban yang lebih tinggi jenjangnya, (2) kontribusi signifikan tim dan personel terhadap pencapaian sasaran-sasaran strategik pusat pertanggungjawaban yang menjadi tempat kerja tim dan personnel yang bersangkutan.

Kaplan (1996) menjelaskan bahwa organisasi-organisasi besar menggunakan beberapa mekanisme yang saling terkait untuk menerjemahkan strategi dan Balanced Scorecard ke dalam tujuan dan ukuran yang akan mempengaruhi prioritas perorangan dan tim. Ada tiga mekanisme yang digunakan yaitu: 
1. Program Komunikasi dan Pendidikan

Semua pekerja baik itu eksekutif senior atau dewan direksi dapat memahami strategi dan perilaku yang dibutuhkan agar tujuan strategis dapat tercapai. Balanced Scorecard seharusnya dapat meningkatkan pemahaman setiap pekerja tentang strategi organisasi dan dapat meningkatkan motivasi demi tercapainya tujuan strategis. Program komunikasi dan pendidikam suatu organisasi tidak hanya harus komprehensif tetapi juga harus secara periodik. Berbagai sarana komunikasi dapat digunakan untuk meluncurkan program Balanced Scorecard yaitu dengan menggunakan video, mengadakan rapat, melalui newsletter dan brosur.

Pengumuman awal ini kemudian ditindaklanjuti secara terus menerus dengan cara melaporkan ukuran dan hasil dari scorecard melalui bulletin board, newsletter, groupware, dan melalui jaringan elektronis. Kaplan (1996) mencontohkan bahwa Pioneer Petrolium menggunakan newsletter bulanan untuk menyediakan informasi tentang Balanced
Scorecard mereka.

2. Program Penetapan Tujuan

Pengkomunikasian tujuan dan ukuran Balanced Scorecard adalah langkah awal dalam menghasilkan komitmen perorangan terhadap strategi unit bisnis. Bagaimnapun juga, tujuan dan ukuran strategis di tingkat yang lebih tinggi perlu diterjemahkan ke dalam tindakan yang dapat diambil oleh setiap orang dalam memberikan kontribusi sehingga tujuan organisasi dapat tercapai. Sebagai contoh, pengiriman barang yang tepat waktu bagi perspektif pelanggan unit bisnis dapat diterjemahkan ke dalam suatu tujuan yaitu misalkan saja berupa pengurangan waktu pemasangan atau pemindahan pesanan yang cepat dari suatu proses ke proses lainnya. Dengan cara ini, upaya peningkatan menjadi selaras dengan faktor keberhasilan organisasi secara keseluruhan. Balanced Scorecard pada tingkat unit bisnis dapat diterjemahkan ke dalam sebuah scorecard yang terkait untuk departemen di tingkat yang lebih rendah, tim dan perorangan.

Kaplan (1996) memberikan contoh pada perusahaan real 
estate yang mana pada divisi real estate dari sebuah organisasi ritel besar bermaksud untuk memecah scorecard unit bisnis ke departemen dan tim tingkat berikutnya. Setiap tim menggunakan scorecard unit bisnis sebagai acuan. Tim kemudian mengidentifikasi tujuan dan ukuran pada scorecard unit bisnis tersebut. Para manajer mengembangkan sebuah scorecard tim yang menerjemahkan tujuan dan ukuran strategis tingkat yang lebih tinggi ke dalam inisiatif dan ukuran tim lokal. Contoh tersebut menggambarkan bahwa para manajer menjadi lebih berkomitmen untuk melaksanakan strategi dan mencapai tujuan organisasi secara keseluruhan.

3. Keterkaitan dengan Sistem Imbalan

Keselarasan dengan strategi akhirnya harus dimotivasi melalui sistem insentif dan imbalan. Kaplan (1996) memberikan contoh bahwa sebuah organisasi mengubah perhitungan bonus untuk eksekutif seniornya yang semula berdasarkan ROCE tahunan; sekarang bonus 50 persen didasarkan kepada tercapainya target nilai tambah ekonomis dan 50 persen lainnya didasarkan kepada tiga perspektif non financial. Manfaat dari kebijakan tersebut adalah kepentingan financial para manajer dapat diselaraskan dengan upaya pencapaian tujuan strategis unit bisnis. Para manajer tidak akan memperoleh kompensasi insentif jika kinerja aktual dalam suatu periode tidak mencapai ambang batas pada salah satu ukuran yang ditetapkan. Batasan ini harus dapat memotivasi kinerja yang seimbang pada perspektif financial, pelanggan, proses bisnis internal serta pembelajaran dan pertumbuhan.

\section{METODE}

Pada tahun 1808 didirikan sebuah bengkel peralatan militer di Surabaya dengan nama Artillerie Constructie Winkel (ACW), bengkel ini berkembang menjadi sebuah pabrik dan sesudah mengalami perubahan nama pengelola kemudian dipindahkan lokasinya ke Bandung pada tahun 1923.

Pemerintah Belanda pada tahun 1950 menyerahkan pabrik tersebut kepada Pemerintah Indonesia, kemudian pabrik tersebut diberi nama Pabrik Senjata dan Mesiu (PSM) 
yang berlokasi di PT. PINDAD sekarang ini. Sejak saat itu PT. PINDAD berubah menjadi sebuah industri alat peralatan militer yang dikelola oleh Angkatan Darat. PT. PINDAD berubah status menjadi Badan Usaha Milik Negara (BUMN) dengan nama PT. PINDAD (Persero) pada tanggak 29 April 1983, kemudian pada tahun 1989 perusahaan ini berada dibawah pembinaan Badan Pengelola Industri Strategis (BPIS) yang kemudian pada tahun 1999 berubah menjadi PT. Pakarya Industri (Persero) dan kemudian berubah lagi namanya menjadi PT. Bahana Pakarya Industri Strategis (Persero). Tahun 2002 PT. BPIS (Persero) dibubarkan oleh Pemerintah, dan sejak itu PT. PINDAD beralih status menjadi PT. PINDAD (Persero) yang langsung berada dibawah pembinaan Kementerian BUMN.

PT. Pindad (Persero) adalah Badan Usaha Milik Negara berbentuk perseroan, berkedudukan di bawah koordinasi Menteri Negara Badan Usaha Milik Negara Republik Indonesia dan berkantor pusat di Bandung, dengan kantor-kantor, cabang-cabang, dan perwakilan perwakilannya, baik di dalam maupun di luar wilayah Republik Indonesia.
Penelitian ini dirancang sebagai studi kasus, tujuan dari studi kasus adalah untuk mendapatkan informasi mengenai perspektif tentang suatu organisasi, situasi, kejadian, atau proses pada titik waktu atau suatu periode tertentu. Tujuan studi kasus adalah melakukan penyelidikan secara mendalam mengenai subjek tertentu untuk member gambaran yang lengkap mengenai subjek tertentu (Indrianto, 2002). Dalam penelitian ini peneliti menggunakan pendekatan kualitatif. Menurut (Sugiyono, 2009) penelitian kualitatif adalah suatu metode penelitian yang berlandaskan pada filsafat postpositivisme, digunakan untuk meneliti pada kondisi objek yang alamiah dimana peneliti adalah sebagai instrumen kunci, pengambilan sampel sumber data dilakukan secara purposive, teknik pengumpulan dengan triangulasi, analisis data bersifat induktif/ kualitatif, dan hasil penelitian kualitatif lebih menekankan makna daripada generalisasi.

Jenis data dalam penelitian ini adalah data kualitatif. Yang berupa:

Data sekunder

Studi pustaka dari bukubuku literature, jurnal maupun tulisan lainnya yang berisi kajian teori sebagai dasar untuk 
memperkuat evaluasi yang akan dilakukan.

\section{Data primer}

Data langsung diperoleh dari objek penelitian. Data tersebut merupakan data resmi perusahaan, hasil wawancara maupun observasi terhadap perusahaan. Untuk manajemen akan menggunakan teknik wawancara

Menurut (Sugiyono, 2009), mengemukakan bahwa aktivitas dalam analisis data kualitatif dilakukan secara interaktif dan berlangsung terus menerus sampai tuntas, hingga datanya jenuh. Aktivitas tersebut adalah reduksi data (data reduction), penyajian data (data display), dan conclusion drawing/ verification. Analisa data dalam penelitian ini dilakukan secara deskriptif kualitatif.

Analisa data dalam penelitian ini dilakukan secara deskritif kualitatif. Deskriptif kualitatif ini digunakan untuk menganalisis data yang diperoleh berdasarkan empat perspektif yang ada dalam konsep Balanced Scorecard. Dari hasil penelitian diharapkan akan mendukung tujuan dan manfaat penelitian serta menjawab permasalahan yang telah dirumuskan. Variabel dan definisi operasional, Berdasarkan topik penelitian ini penulis ingin mengevaluasi kinerja PT. PINDAD (Persero) dengan pendekatan Balanced Scorecard, variabel-variabel yang akan diukur adalah variabel yang terdapat dalam Balanced Scorecard kemudian disesuiakan dengan karakteristik organisasi tersebut.

Ukuran kinerja dalam Balanced Scorecard berasal dari visi, strategi dan tujuan perusahaan (Hansen dan Mowen, 2004). Ukuran ini harus diseimbangkan antara ukuran output dan ukuran kepastian (penggerak kinerja), antara ukuran objektif dan subjektif, antara ukuran eksternal dan internal dan antara ukuran keuangan dan non ukuran keuangan. Ukuran kinerja harus secara berhatihati dihubungkan dengan strategi perusahaan.

\section{HASIL DAN PEMBAHASAN}

Evaluasi Perspektif Financial

Ukuran-ukuran dalam perspektif financial yang digunakan oleh PT. PINDAD (Persero) yaitu dilihat dari pertumbuhan dan profitabilitas, solvabilitas serta pengukuran financial dan non-financial, penjualan. Jadi dilihat dari perspektif financial kinerja organisasi sudah baik, tetapi ada beberapa indikator yang realisasinya belum sesuai dengan target yang ditetapkan oleh organisasi. Seperti terlihat pada tabel 
diatas, dari tabel diatas ada beberapa indikator KPI yang memang tidak tercapai, seperti net profit margin kemungkinannya karena adanya penurunan volume penjualan. Apabila net profit margin tidak tercapai pada laporan KPI maka biaya meningkat relatif lebih besar daripada peningkatan penjualannya.

Melihat KPI dari debt equity ratio pun dapat terlihat kalau keterangannya tidak tercapai, yang menggambarkan total hutang yang dimiliki perusahaan dengan modal sendiri yang hubungan antara jumlah pinjaman jangka panjang yang diberikan oleh kreditur dengan jumlah modal sendiri yang diberikan oleh perusahaan itu sendiri, dari sini dapat terlihat bahwa hutang yang digunakan lebih besar dari target yang telah diperkirakan.

Dari KPI cash ratio memberikan keterangan tidak tercapai kemungkinan yang muncul, karena kondisi rasio terlalu tinggi juga kurang baik karena ada dana yang menganggur atau yang tidak atau belum digunakan secara optimal. Kondisi kurang baik ditinjau dari rasio kas karena untuk membayar kewajiban masih memerlukan waktu untuk menjual sebagian dari aktiva lancar lainnya.

\section{Evaluasi Perspektif Customer}

Jadi dilihat dari perspektif customer kinerja organisasi sudah baik hal itu dapat dilihat dari tercapainya target target yang sudah ditetapkan oleh organisasi. Tetapi dengan indikator pada perspektif tersebut sebenarnya penulis melihat bahwa indikator solvabilitas serta pengukuran financial dan nonfinancial, penjualan. Jadi dilihat dari perspektif financial kinerja organisasi sudah baik, tetapi ada beberapa indikator yang realisasinya belum sesuai dengan target yang ditetapkan oleh organisasi. seperti terlihat pada tabel diatas, dari tabel diatas ada beberapa indikator KPI yang memang tidak tercapai, seperti net profit margin kemungkinannya karena adanya penurunan volume penjualan. Apabila net profit margin tidak tercapai pada laporan KPI maka biaya meningkat relatif lebih besar daripada peningkatan penjualannya.

Melihat KPI dari debt equity ratio pun dapat terlihat kalau keterangannya tidak tercapai, yang menggambarkan total hutang yang dimiliki perusahaan dengan modal sendiri yang hubungan antara jumlah pinjaman jangka panjang yang diberikan oleh kreditur dengan jumlah modal sendiri yang diberikan oleh perusahaan itu sendiri, dari sini dapat terlihat bahwa hutang yang 
digunakan lebih besar dari target yang telah diperkirakan.

Dari KPI cash ratio memberikan keterangan tidak tercapai kemungkinan yang muncul, karena kondisi rasio terlalu tinggi juga kurang baik karena ada dana yang menganggur atau yang tidak atau belum digunakan secara optimal. Kondisi kurang baik ditinjau dari rasio kas karena untuk membayar kewajiban masih memerlukan waktu untuk menjual sebagian dari aktiva lancar lainnya.

Evaluasi Perspektif Internal Business Process

Jadi dilihat dari perspektif internal business process kinerja organisasi sudah baik hal itu dapat dilihat dari tercapainya target target yang sudah ditetapkan oleh organisasi. Tindak lanjut terhadap fraud dan jumlah kasus pending perlu dilakukan dan disiasati lebih awal sebelum penyimpangan tersebut mengakibatkan kerugian di kemudian hari. Dan juga akan berpengaruh secara signifikan terhadap kelangsungan usaha perusahaan.

Evaluasi Perspektif Learning \& Growth

Perspektif keempat pada Balanced Scorecard adalah mengembangkan tujuan dan indikator untuk memicu belajar dan tumbuh. Tujuan dalam perspektif ini adalah menyediakan infrastruktur untuk mencapai tujuan dalam tiga perspektif ini adalah menyediakan infrastruktur untuk mencapai tujuan dalam tiga perspektif lainnya. Jadi dilihat dari perspektif learning and growth kinerja organisasi sudah baik hal itu dapat dilihat dari tercapainya target target yang sudah ditetapkan oleh organisasi. Dan juga hal ini disebabkan oleh adanya dana untuk menghasilkan produk, sehingga mengakibatkan meningkatnya kemampuan dan kompetensi pegawai. Produktivitas karyawan ini diperlukan untuk mengetahui kemampuan karyawan dan kompetensi pegawai dalam menghasilkan porduk sesuai dengan kapasitas dan sumber daya di perusahaan, pemasok dan tentu untuk PT. PINDAD (Persero).

\section{KESIMPULAN, IMPLIKASI DAN KETERBATASAN PENELITIAN}

Pada saat ini persaingan bisnis antar perusahaan-perusahaan di dunia semakin ketat sehingga menuntut para pengambil kebijakan untuk selalu bertindak dan berperilaku efisien dan seoptimal mungkin menciptakan utilisasi dalam proses produksinya. Untuk itu perusahaan-perusahaan harus 
melakukan berbagai macam strategi dalam menghadapi persaingan tersebut agar perusahaan dapat terus bertahan, berkembang dan maju sehingga tidak kalah bersaing dan hilang keberadaannya karena kalah dalam persaingan.

Selanjutnya ukuran kinerja keuangan merupakan ukuran keuangan yang mana ukuran secara fungsional, tidak secara keseluruhan. Hal ini disebabkan karena pada umumnya ukuran kinerja keuangan disiapkan oleh masing-masing area fungsional, misalnya pemasaran dan keuangan. Dengan demikian kinerja keuangan tidak dapat dijadikan sebagai alat untuk mencerminkan perusahaan secara keseluruhan. Keterbatasan ukuran kinerja yang lain adalah fokus pada keuntungan jangka pendek, sehingga keuntungan jangka panjang akan terabaikan dan menjadi tidak relevan untuk dijadikan sebagai dasar keputusan bagi beberapa level dalam organisasi.

Dari hasil analisis peneliti menyimpulkan bahwa penerapan Balanced Scorecard yang sudah diterapkan di PT. PINDAD (Persero) terintegrasi dengan baik sehingga memilki hubungan sebab akibat. Hal ini dapat dilihat dari penerapan Balanced Scorecard yang sudah diterapkan hingga ke level unitnya.
Penilaian kinerja pun sudah sesuai berdasarkan dengan empat perspektif pun sudah baik. Karena berdasarkan target dan realisasi yang sudah dicapai yang dilihat dari laporan capaian Key Performance Indicator yang menjadi tolak ukur bagi manajemen semua target yang ditetapkan sudah tercapai dengan baik. Walaupun ada beberapa indicator ada yang tidak tercapai tetapi persentase nya tidak terlalu signifikan.

Dalam pernyataan misi terdapat beberapa unsur yang menjelaskan tindakan dan strategi yang dilakukan PT. PINDAD (Persero) untuk mendukung tercapainya visi. Pertama, disebutkan bahwa PT. PINDAD (Persero) Menjadi Produsen Peralatan Pertahanan dan Keamanan terkemuka di Asia pada tahun 2023, melalui upaya inovasi produk dan kemitraan strategik. Melalui visi yang dimiliki oleh PT. PINDAD (Persero) maka penulis dapat mengatakan bahwa visi yang dimiliki oleh PT. PINDAD (Persero) sudah mencerminkan gambaran masa depan perusahaan yang ingin dicapai kedepannya.

Sedangkan misi PT. PINDAD (Persero) adalah melaksanakan usaha terpadu di bidang peralatan pertahanan dan keamanan serta peralatan industrial untuk 
mendukung pembangunan nasional dan secara khusus untuk mendukung pertahanan dan keamanan negara. Dari pernyataan misi tersebut tersebut sudah baik, bahkan sudah memenuhi kriteria misi yang efektif karena dapat disimpulkan bahwa misi yang dimiliki oleh PT. PINDAD (Persero) menggambarkan tujuan jangka panjang perusahaan sudah dapat terlihat.

Rencana strategis yang ada di PT. PINDAD (Persero), strategi yang diambil PT. PINDAD (Persero) dalam menjalankan visi dan misi perusahaan adalah secara konsisten dan kontinyu melakukan pembaharuan dan pengembangan dalam hal fasilitas dan kemampuan yang telah dimiliki, seperti memenuhi perlengkapan mesinmesin serta peningkatan budaya kerja dari perusahaan, sehingga nantinya PT. PINDAD dapat memenuhi standar pasar industri. Maka dari itu visi PT. PINDAD (Persero) dapat memberikan gambaran akan perkembangan core business yang diinginkan. Maksud tujuan dan sasaran PT. PINDAD (Persero) adalah mampu menyediakan kebutuhan alutsista secara mandiri untuk mendukung penyelenggaraan pertahanan dan keamanan Negara Republik Indonesia dan meningkatkan potensi perusahaan untuk mendapatkan peluang usaha yang menjamin masa depan perusahaan melalui sinergi internal dan eksternal.

Penilaian kinerja berdasarkan empat perspektif:

1. Perspektif Financial

Perspektif financial kinerja organisasi sudah baik hanya ada beberapa indikator yang realisasinya belum sesuai dengan target yang ditetapkan oleh organisasi.

2. Perspektif Customer

Perspektif customer kinerja organisasi sudah baik hal itu dapat dilihat dari tercapainya target target yang sudah ditetapkan oleh organisasi. Namun belum ada pengukuran kinerja yang khusus untuk mengukur tingkat kepuasan pelanggan. Karena berdasarkan dengan laporan manajemen KPI nya baru dilihat dari pertumbuhan pendapatan penjualan dan on time delivery.

3. Perspektif Internal Business Process

Perspektif internal business process kinerja organisasi sudah baik hal itu dapat dilihat dari tercapainya target target yang sudah ditetapkan oleh organisasi. 
4. Perspektif Learn and Growth

$$
\text { Perspektif learn and }
$$

growth kinerja organisasi sudah baik hal itu dapat dilihat dari tercapainya target target yang sudah ditetapkan oleh organisasi

Sebagai keterbatasan, peneliti tidak mendapatkan catatan laporan sampai ke divisi dan unit nya, tetapi yang didapatkan oleh penulis hanya berdasarkan dengan laporan pada tingkat korporat saja. Walaupun Balanced Scorecard sudah diterapkan sampai level unit divisinya.

Rekomendasi yang dapat ditawarkan adalah:

1. Evaluasi kinerja dengan Balanced Scorecard dengan menggunakan indikator kinerja dari masing- masing perpektif dapat disesuaikan dengan kebutuhan dan bergantung kepada kinerja mana yang perlu mendapat tekanan dan perhatian lebih lanjut. Dengan dilihat indikator mana yang target nya belum tercapai pada realisasinya.

2. Perusahaan harus terus berusaha meningkatkan sumber daya manusia yang ada melalui pendidikan dan pelatihan, serta mempertahankan kepuasan dari karyawan.

\section{REFERENSI}

Anthony, Robert T dan Govindarajan, V. 2002. Management Control System 11th edisi terjemahan. Jakarta: Salemba-Empat

Bawono. 2006. Multivariate Analysis dengan SPSS. Salatiga: StainSalatiga Press.

Hansen, Don R dan Mowen. 2004. Management Accounting 7th edisi terjemahan. Jakarta: SalembaEmpat.

Hartono Jogiyanto. 2011. Metodologi Penelitian Bisnis. Yogyakarta: BPFE UGM.

Indriantoro, Nur dan Bambang Sutopo. 2002. Metodologi Penelitian Bisnis untuk Akuntansi dan Manajemen. Yogyakarta: BPFE.

Kaplan, Robert S. dan Davis P. Norton. 1996. The Balance Scorecard-Measures That Drive Performance. BostonMassachusetts: Harvard Business School Press

Kaplan, Robert S dan David P. Norton. 2001. The Strategy-Focused Organization. BostonMassachusetts: Harvard Business School Press

Kaplan, Robert S. dan Davis P. Norton. 2001. Transforming the Balanced scorecard from Performance Measurement to Strategic Management - Part I. Accounting Horizons, Vol 15, No.2, June, pp.87-10.

Kaplan, Robert S. dan Davis P.Norton. 2001. Transforming the Balanced scorecard from Performance Measurement to Strategic 
Management-Part II. Accounting Horizons, Vol 15, No.2, June, pp.147-160.

Keputusan Menteri Badan Usaha Milik Negara Nomor:KEP102/MBU/2002 Tentang Penyusunan Rencana Jangka Panjang Badan Usaha Milik Negara Menteri Badan Usaha Milik Negara

Kussetya Ciptani, Monika. 2000. Balanced Scorecard Sebagai pengukuran Masa Depan: Suatu Pengantar. Universitas Kristen Petra $\begin{array}{rrr}\text { Mulyadi. 2009. Sistem } & \text { Terpadu } \\ \text { Pengelolaan } & \text { Kinerja } & \text { Personel }\end{array}$
Berbasis Balanced Scorecard. UPP STIM YKPN

Mulyadi. 2001. Balanced Scorecard: Alat Manajemen Kontemporer Untuk Pelipatgandaan Kinerja Keuangan Perusahaan. Jakarta: Salemba Empat.

Pusat Analisis dan Harmonisasi Sekretariat Jenderal Kementerian Keuangan, 2010 Panduan Pengelolaan Kinerja Berbasis Balanced Scorecard di Lingkungan Kementerian Keuangan

Sugiyono, 2000, Metode Penelitian Bisnis, Alfabeta 